\title{
WYKORZYSTANIE POJĘCIA GRANICA W ORGANIZACJACH - IDENTYFIKACJA OBSZARÓW BADAWCZYCH
}

DOI: 10.33141/po.2019.12.03

\section{Dorota Jendza, Piotr Wróbel}

\section{Wprowadzenie}

hcąc lepiej zrozumieć funkcjonowanie organizacji oraz ludzi w organizacjach, poszukujemy konstruktów i pojęć z innych obszarów i dziedzin. Niejednokrotnie pozwala to wzbogacić naukę, ukazując nowe perspektywy analizy zjawisk, rzucając nowe światło na dotychczasowe mechanizmy. Jednym $\mathrm{z}$ takich terminów, który od pewnego czasu jest wykorzystywany w badaniach organizacji, jest pojęcie granica ${ }^{1}$.

Czy, dlaczego i w jakim zakresie warto w takich badaniach wykorzystywać kategorię granicy? Autorzy artykułu spróbują odpowiedzieć na te pytania, stawiając sobie jako cele:

- identyfikację dotychczasowej skali i zakresu zastosowania pojęcia granica w badaniach organizacji,

- określenie możliwości, które zapewnia wykorzystanie kategorii granicy do interpretacji zjawisk zachodzących w organizacjach, a dzięki temu do lepszego zrozumienia ich funkcjonowania.

$\mathrm{Na}$ początku dokonano analizy bibliometrycznej wykorzystania pojęcia granica $w$ badaniach, a następnie przeanalizowano wybrane artykuły z zakresu zarządzania oraz psychologii organizacji. Dobór publikacji miał charakter celowy - miał służyć poznaniu jak najszerszego spektrum problemów badawczych, w których wykorzystywane jest podejście oparte na granicach. Tekst wpisuje się w dyskusję nad problemem granic organizacji, która została zapoczątkowana wśród krajowych badaczy przez S. Cyferta (2012a).

\section{Wykorzystanie pojęcia granica w nauce - analiza bibliometryczna}

D óżnorodność rozumienia pojęcia granica powoduNe, że jest używane w różnych kontekstach i celach w wielu dziedzinach i dyscyplinach nauki. W celu poznania skali i zakresu zastosowania pojęcia granica $\mathrm{w}$ nauce, $\mathrm{w}$ szczególności $\mathrm{w}$ badaniach organizacji, przeanalizowano zawartość bazy artykułów naukowych dimensions.ai, zawierającej opis $140 \mathrm{mln}$ publikacji, patentów i grantów. W pierwszym etapie zidentyfikowano badania, w których tytule lub streszczeniu wykorzystano pojęcie granica (rys. 1). W drugim etapie dokonano przeglądu takich badań $\mathrm{w}$ ramach obszaru badawczego "Business and Management". Najwięcej takich publikacji dotyczyło badań z zakresu zarządzania oraz psychologii organizacji, dlatego w dalszej części artykułu przeanalizowano badania $\mathrm{z}$ tych dwóch obszarów. Dodatkowym źródłem analizowanych artykułów były bazy: EBSCOhost, PsycARTICLES, PsycINFO. 
$\mathrm{Z}$ przeprowadzonej analizy wynika, że $\mathrm{z}$ roku na rok wykorzystanie kategorii granicy w badaniach naukowych istotnie wzrasta. Termin granica jest najczęściej wykorzystywany:

- w przypadku terminu boundary w: inżynierii materiałowej, inżynierii interdyscyplinarnej, matematyce, sztucznej inteligencji;

- w przypadku terminu frontier w: ekonomii, studiach historycznych, chemii fizycznej, sztucznej inteligencji.

Problem granic jest jednak dużo rzadziej podejmowany w badaniach organizacji. W obszarze określonym jako „Business and Management" w latach 2010-2018 identyfikowano jedynie kilkaset artykułów rocznie posiadających w tytule lub streszczeniu termin granica (frontier, boundary), choć należy podkreślić, że ich liczba szybko rosła (rys. 2).

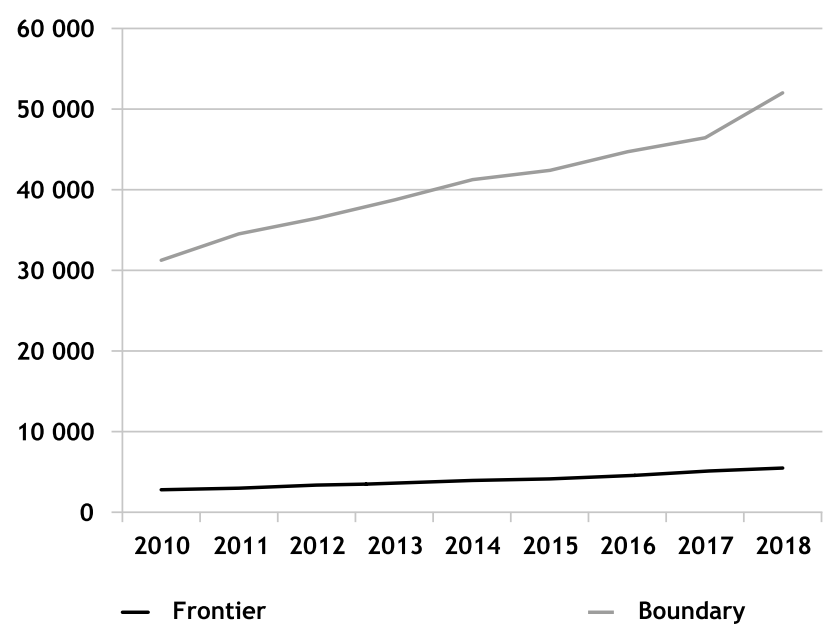

Rys. 1. Liczba artykułów naukowych, w których tytule lub streszczeniu pojawił się termin granica (wszystkie dziedziny nauki) Źródto: opracowanie wtasne na podstawie danych z dimensions.ai (data dostępu: 08.05.2019 r.)

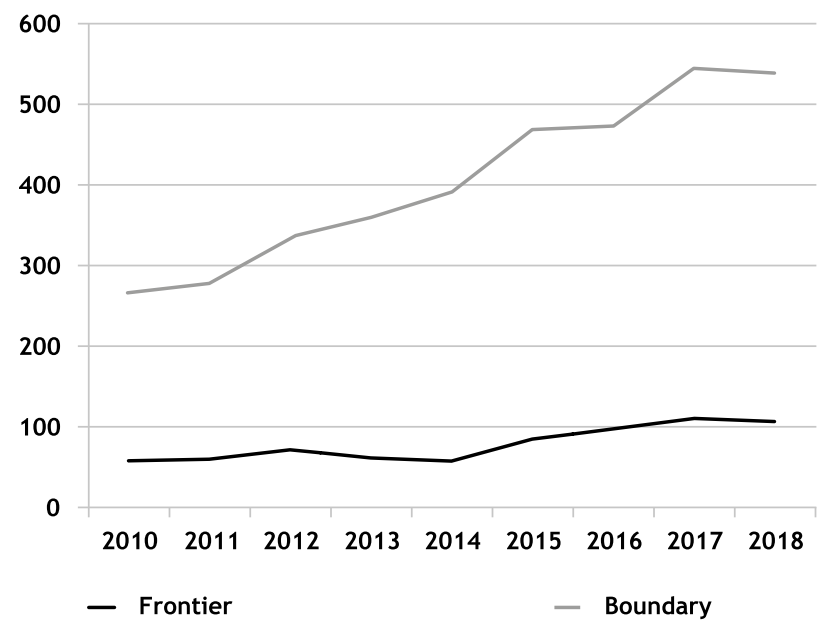

Rys. 2. Liczba artykutów naukowych, w których tytule lub streszczeniu pojawit się termin granica (obszar: Business and Management)

Źródło: opracowanie własne na podstawie danych z dimensions.ai (data dostępu: 08.05.2019 r.)

W matematyce termin granice najczęściej odnosi się do granic funkcji oraz granic ciągów. W tym ujęciu granice traktowane są jako wartości brzegowe, do których elementy danej funkcji lub ciągu zbliżają się. S. Cyfert (2012a, s. 12) podkreśla ograniczający sposób takiego definiowania granic, powodujący, że pewne wartości nie mogą zostać osiągnięte lub przekroczone.

W inżynierii materiałowej pojęcie granica wykorzystywane jest do analizy wytrzymałości materiałów i konstrukcji. Przy ocenie wytrzymałości danego materiału lub konstrukcji na obciążenia zewnętrzne określa się m.in. granicę plastyczności, sprężystości oraz zmęczenia. W zależności od granicy plastyczności danego materiału wyliczane są dopuszczalne naprężenia. Przekroczenie przez naprężenia granicy plastyczności może prowadzić do powstania trwałych odkształceń materiału (Blicharski, 2001, s. 575).

$\mathrm{W}$ geografii, historii, naukach o polityce i administracji oraz naukach prawnych granice najczęściej rozumiane są w kontekście granic państwowych. Granica staje się „miejscem podziału przestrzeni, czasu i polityki, w którym następuje synteza stosunków politycznych, militarnych, gospodarczych i ideologii" (Foucher, 1991).

W ekonomii istnieje szereg teorii określanych jako granice wzrostu, które kwestionują możliwość nieustannego wzrostu gospodarczego (Burda, Wyplosz, 2009, s. 54). Badacze w szczególności podkreślają ekologiczne, społeczne i technologiczne granice wzrostu. Z drugiej strony, krytycy wskazują, że granice wzrostu dzięki innowacyjności ludzkości mogą być przesuwane.

$\mathrm{W}$ psychologii pojęcie granica jest centralnym terminem opisującym człowieka. Granica jest pewnym progiem, oddzielającym coś znanego od nieznanego bądź miejscem, w którym człowiek chce zachować dotychczasowy stan i jednocześnie przejść w stronę nieznanego (Mindell, 1995, s. 135; Dudek, 2006, s. 60-65). W tym nurcie podejmowane są m.in. problemy dotyczące granic umysłu - pomiędzy otwartością a konserwatywnymi przekonaniami kulturowymi i ekonomicznymi, czy też granice moralne i etyczne $\mathrm{w}$ procesie podejmowania decyzji. Można powiedzieć, że psychologowie używają tego pojęcia do poznania tożsamości człowieka: kim jest i jakie ma ograniczenia. Granica jest więc kategorią, która umożliwia zrozumienie i budowanie relacji intrapersonalnej.

Natomiast J. Kozielecki (1987, s. 48) traktuje granicę jako zakres dotychczasowych osiągnięć jednostki. Można ją nazwać granicą działań indywidualnych lub granicą osobistą. W tym rozumieniu granica staje się raczej linią demarkacyjną oddzielającą to, czym człowiek jest i co posiada, od tego, czym jeszcze nie jest, ale czym może być dzięki podjęciu różnych działań transgresyjnych. Jest pojęciem definiującym tożsamość człowieka, a działania transgresyjne pozwalają na przekraczanie granic osobowości i norm społecznych, zwłaszcza moralnych.

Granic psychologowie używają również do określenia funkcjonowania i obcowania człowieka $\mathrm{z}$ innymi ludźmi. $\mathrm{W}$ tym aspekcie termin ten używany jest do opisu relacji interpersonalnych. W różnych relacjach ujawniane są granice etyczne, moralne i zaufania.

O szerokim zakresie zastosowania problematyki granic $\mathrm{w}$ badaniach naukowych $\mathrm{w}$ wielu dziedzinach świadczy również wykorzystanie tego pojęcia $\mathrm{w}$ nazewnictwie 
czasopism naukowych. Szwajcarski wydawca Frontiers publikuje 69 czasopism ze słowem granice w tytule, np. Frontiers in Chemistry, Frontiers in Immunology, Frontiers in Psychology, Frontiers in Sustainable Cities.

\section{Pojęcie granica w badaniach organizacji}

W badaniach dotyczących organizacji kategoria granicy występuje w różnych kontekstach i obszarach badawczych, np. zarządzania strategicznego, zarządzania kapitałem społecznym, przywództwa. Problem granic nie jest nowy, już w 1937 roku R. Coase rozważał istotę granic, badając naturę organizacji, a w latach 50 . ubiegłego wieku problem granic stał się częścią teorii systemów (Coase, 1937). Najczęściej jednak, jak podkreśla P. Pachura (2018, s. 152), zagadnienie granic nie stanowi głównego problemu badawczego, a pojawia się jako pewien wątek poboczny w badaniach. Być może dzieje się tak dlatego, że kategoria granicy jest opisywana jednocześnie jako konkretna i abstrakcyjna, łatwo uchwytna i wymykająca się uogólnieniom (Barabasz, 2014, s. 68) oraz kontrowersyjna. Tymczasem w badaniach dotyczących organizacji wielu badaczy poszukuje jednoznacznych odpowiedzi na postawione pytania.

Niemniej granice istnieją, choć często są niewidoczne. Występują nie tylko $\mathrm{w}$ organizacjach, ale również w świecie nauki: pomiędzy dziedzinami, dyscyplinami, subdyscyplinami, teorią i praktyką. W pewnym stopniu przyczyniają się także do tego, że każda $\mathrm{z}$ dziedzin naukowych wypracowuje swoje odrębne metody, teorie i język. Co więcej, wielu badaczy stara się nie przekraczać granicy swojej dyscypliny, wychodząc z założenia, że jest to bezpieczniejsze. J. Hensel (2017, s. 19) dodatkowo podkreśla, że naukowcy raczej koncentrują się na eksploatacji istniejących teorii i ich rozwijaniu, a nie poszukiwaniu nowych. Być może są to przyczyny niewielkiej skali wykorzystania w badaniach organizacji tak interdyscyplinarnej i stosunkowo nowej kategorii, jaką jest granica.

W dalszej części artykułu przedstawiono obszary badawcze $\mathrm{w}$ podziale na występujące $\mathrm{w}$ badaniach $\mathrm{z}$ zakresu zarządzania oraz psychologii organizacji.

\section{Badania z zakresu zarządzania}

$\mathbf{P}$ oczątkowo granice w badaniach organizacji traktowane były jako linie oddzielające wnętrze od tego co na zewnątrz, z zauważalnymi interakcjami między nimi. Podstawowym celem granic było rozdzielanie ludzi, procesów, zasobów. Badacze wskazywali na małą elastyczność granic lub jej brak. Z czasem jednak zaczęto postrzegać granice jako organiczne, biologiczne, przepuszczalne formy zbliżone do elastycznej membrany. Podkreślano wzajemne oddziaływanie organizacji i otoczenia. W tym podejściu ważne staje się rozróżnienie granic organizacji od granic w organizacjach, czyli granic zewnętrznych od wewnętrznych.

Granice w relacji organizacja - otoczenie wiążą się z klasycznym dylematem: wytwarzać, kupować czy współpracować? Jak zauważa S. Cyfert (2012a, s. 16-18), naturę granic organizacji w największym stopniu wyjaśniają teoria kosztów transakcyjnych i teoria zasobowa. W teorii kosztów transakcyjnych wskazane są warunki skłaniające do wyboru jednej ze ścieżek rozwoju organizacji - wewnętrznego lub zewnętrznego. Należą do nich: poziom niepewności w otoczeniu wpływający na warunki zawierania transakcji, poziom specjalizacji zasobów angażowanych do danej działalności, częstotliwość realizowania danej działalności. Wybór pomiędzy rozwojem wewnętrznym a zewnętrznym w poszczególnych obszarach aktywności organizacji w bezpośredni sposób wpływa na jej granice zewnętrzne. Z kolei w teorii zasobowej zakłada się, że koncepcja długofalowego rozwoju organizacji powinna być tworzona $\mathrm{z}$ uwzględnieniem ograniczonych i trudnych do imitacji zasobów będących w jej dyspozycji. $\mathrm{W}$ rezultacie granice organizacji są zdeterminowane przez posiadane zasoby.

T. Hernes (2003, s. 36-37) zauważa, że z jednej strony granic znajdują się zewnętrzne oczekiwania, a $\mathrm{z}$ drugiej - dążenie do wewnętrznej ochrony. Są więc kategorią porządkującą ludzkie działania i interakcje oraz mechanizmami umożliwiającymi te działania, prowadząc do integracji organizacji z otoczeniem. Paradoks granic polega na tym, że z jednej strony coś ograniczają, a z drugiej - umożliwiają (Berg, Smith, 1990, s. 116). Badacze podkreślają, że fizyczne granice służą do wiązania zasobów w czasie i przestrzeni. Mają więc moc wiążącą, zapewniają stabilność i przestrzeń. Służą do tworzenia i konsolidowania oraz budowania poczucia sprawowania kontroli (Hernes, 2003, s. 38). Granice są pewnymi buforami dla podstawowej działalności chroniącymi ją przed wahaniami środowiskowymi; pełnią funkcję filtrów.

N. Paulsen i T. Hernes (2003, s. 3) zwracają uwagę, że w literaturze dotyczącej organizacji granice są często traktowane jako rezultat procesu organizowania. Budowa granic zewnętrznych i wewnętrznych staje się więc narzędziem organizowania pracy, wprowadzania porządku w miejsce chaosu. Granice wewnętrzne determinują podział pracy, zakres i poziom specjalizacji uczestników organizacji. Ich źródłem są schematy organizacyjne, mapy procesów, procedury, ale także bardziej subtelne działania odnoszące się do tworzenia zespołów przez menedżerów.

H. Dumez i A. Jeunemaitre (2010, s. 152) podkreślają, że nie ma naturalnych granic organizacyjnych, zawsze są one wynikiem pewnych działań i decyzji. Co więcej, raz ustanowione granice mają tendencję do zakorzeniania się i umacniania.

Z czasem oprócz granic fizycznych, zewnętrznych i wewnętrznych zaczęto badać granice społeczne, które pozwalają organizacji lub zespołom odróżnić się od innych. Badacze opisują, że granica może istnieć pomiędzy „innością” a „identycznością”. Uważają, że tożsamość organizacji opisuje to, co ludzie określają jako centralne, charakterystyczne i trwałe w swojej organizacji. Granice społeczne zapewniają ochronę grup, gdy członkowie postrzegają, że ich tożsamość jest zagrożona. Takie granice służą do tworzenia i zachowywania norm behawioralnych, jak też do zachowań podtrzymujących wzorce 
władzy społecznej (Hernes, 2003, s. 38). Mogą służyć do kształtowania $\mathrm{w}$ organizacjach poczucia odrębności - organizacyjnej tożsamości. Jedną z konsekwencji posługiwania się pojęciem tożsamości staje się problematyka psychologicznych granic, zarówno wewnątrz organizacji, jak i między organizacją a obiektami zewnętrznymi. Takimi granicami dla grupy są struktury społeczne, tworzone w celu zabezpieczenia przed lękiem. Granice przestrzenne i czasowe wydają się łatwe do zauważenia. Granice psychologiczne są znacznie trudniejsze do zlokalizowania i zrozumienia. Mogą bowiem opierać się na wyobrażeniach, iluzjach, wydawać się dla ludzi spoza organizacji pozbawione sensu, podczas gdy dla samej organizacji są niezwykle ważne. Przejawy ich istnienia można zaobserwować podczas wprowadzania zmian w organizacjach (Barabasz, 2008, s. 137).

J.M.T. Balmer i A. Wilson (1998) uważają, że tożsamość organizacyjna składa się z centralnych, esencjonalnych dla organizacji elementów, które są trwałe w długim okresie i wyróżniają organizację z otoczenia. Zgodnie z tym podejściem tożsamość jest zakorzeniona w zachowaniach pracowników. Zdaniem autorów, tożsamość określona jest przez etos, cele, wartości, a także poczucie indywidualności, umożliwiające wyróżnienie się w konkurencyjnym środowisku.

Tak samo, jak dla jednostek, tak i dla organizacji, kluczowe staje się stworzenie i chronienie swoich granic, ponieważ to one dają poczucie stałości i ciągłości, a to z kolei służy redukcji lęku (Barabasz, 2008, s. 138).

Jednak w badaniach organizacji sieciowych i wirtualnych podkreśla się, że stabilne i wyraźne granice odchodzą w przeszłość (Perechuda, 2000, s. 312-317). Granice w wyniku interakcji organizacji i otoczenia wciąż się zmieniają. Co więcej, niektórzy autorzy (Ashkenas i in., 1984, Hirschhorn, Gilmore, 1992) zaczynają używać terminu organizacje bez granic (boundaryless organization). $\mathrm{Z}$ takim poglądem zdecydowanie polemizują S. Cyfert i K. Krzakiewicz (2014, s. 53-57), wskazując, że każda organizacja potrzebuje wyraźnie określonych granic, a w szczególności dotyczy to organizacji sieciowych i wirtualnych. W przeciwnym razie istniałyby otwarte organizacje bez granic, do których mógłby się włączyć dowolny podmiot, który wyraziłby taką wolę. Badacze opisują cztery rodzaje granic, które zapewniają funkcjonowanie organizacji sieciowych i wirtualnych: granice władzy, granice kompetencji, granice efektywności oraz granice kultury organizacyjnej. Wskazane granice nie mają trwałego i niezmiennego w czasie charakteru, co więcej powinny podlegać nieustannym przekształceniom.

Ciekawe podejście proponuje W. Czakon (2014, s. 92), który wskazuje na potrzebę eksploracji międzyorganizacyjnego pola badawczego ograniczonego z każdej strony granicami pojedynczych organizacji. Otwiera to możliwość badania granic sieci. A. Marciszewska i G. Jokiel (2019), analizując problemy w zarządzaniu projektami przez sieci międzyorganizacyjne, wskazują na trudności w wytyczaniu granic takich sieci. W ten nurt wpisują się badania B. Barczak (2015), która analizuje sposoby definiowania i wyznaczania granic sieci organizacyjnych.
Specyficznego podejścia do budowy granic wymagają elastyczne organizacje. Jak zauważają L. Hirschhorn i T. Gilmore (1992, s. 5, 7), budowa elastycznych organizacji prowadzi do eliminacji lub osłabienia tradycyjnych granic $\mathrm{w}$ organizacjach. Wynika to ze zmniejszającej się hierarchii czy też zmiany charakteru geograficznych granic organizacji. $Z$ drugiej strony pojawiają się nowe granice, a niektóre dotychczasowe zyskują na znaczeniu. Należą do nich: granice władzy, granice polityczne, granice identyfikacji, granice zadań. To granice, które rzadko mają charakter fizyczny, a raczej mentalny i symboliczny.

Przedmiotem zainteresowania badaczy są również działania podejmowane na granicy organizacji $\mathrm{z}$ otoczeniem, $w$ tym celu używany jest termin praca na pograniczu (boundary work). D. Chitra i M.P. Ganesh (2017) wyróżniają role pełnione przez pracowników organizacji na tzw. pograniczu: zwiadowca, ambasador, koordynator zadań, wartownik, strażnik. Organizacje podejmują różne aktywności w tym zakresie: przekraczanie, wzmacnianie i buforowanie granic, reprezentowanie, prowadzenie rozpoznania otoczenia, koordynowanie zadań. S. Cyfert (2012b) analizuje mechanizmy zarządzania granicami organizacji i granicami w organizacji. Przyjmując założenie o dążeniu organizacji do równowagi z otoczeniem, wyróżnia trzy mechanizmy zarządzania granicami: rozszerzanie, skracanie i buforowanie granic. W.C. Clark z zespołem (2010, s. 1) badał współpracę świata nauki ze społeczeństwem w celu praktycznego wykorzystania stworzonej wiedzy. Autorzy wskazują, że zbyt mała przenikalność granic powoduje, że przepływ wiedzy jest niewielki. $Z$ drugiej strony zniesienie granic rodzi ryzyko upolitycznienia sfery nauki. Badacze konkludują, że utrzymanie granic jest istotne, jednak dodatkowo konieczne są aktywne działania na pograniczu tych dwóch światów.

\section{Badania z zakresu psychologii organizacji}

nterdyscyplinarny charakter kategorii granicy jest w szczególności wykorzystywany przez badaczy wychodzących poza ramy swojej dyscypliny naukowej. Jest to widoczne na przykład w badaniach organizacji łączących nauki o zarządzaniu i jakości z psychologią.

Badacze zwracają uwagę na rolę identyfikacji grupowej $\mathrm{w}$ zrozumieniu zachowań jednostek w organizacji. Podkreśla się, że ludzie rozwijają się wraz ze swoimi grupami, a tożsamości wywierają silny wpływ na postawy i postrzeganie pracowników, co wpływa na budowanie relacji grupowych czy organizacyjnych. Wyróżniane są granice, które mogą stać się źródłem tworzenia grup tożsamościowych - granice płci, wieku, pochodzenia, rasy, stanowisk, zadań i doświadczenia (Paulsen, 2003, s. 17-18).

R. Kislov (2018) analizuje wpływ granic na funkcjonowanie zespołów pracowniczych. W przypadku zespołów zamkniętych granice są utrzymywane w celu budowy tożsamości i integralności zespołu oraz ochrony członków zespołu przed niepożądanymi wpływami zewnętrznymi. $\mathrm{W}$ otwartych zespołach granice traktowane są jako łącznik z otoczeniem, który umożliwia pozyskiwanie nowych kompetencji oraz intensyfikację współpracy. 
Granice umożliwiają sprawowanie kontroli wewnętrznej i zewnętrznej. R. De Board (1978) uważa, że grupy o wyraźnych granicach są efektywniejsze, a te o niewyraźnych granicach są mniej efektywne. Jasno zdefiniowane granice umożliwiają skoncentrowane działania zwłaszcza w organizacjach ideologicznych czy też w organizacjach o oczekiwanej wysokiej wydajności (Weick, Roberts, 1993).

N. Panteli (2003, s. 77, 88) podkreśla znaczenie i aktywną rolę jednostek w tworzeniu granic, a nawet podtrzymywaniu tradycyjnych granic niezależnie od zmian organizacyjnych. Badacze wręcz uważają, że granice tworzone są w umysłach ludzi, którzy wchodzą w interakcję międzyludzką. Granice tworzą wrażenie, a nawet pozwalają zarządzać wrażeniem wywieranym przez jednostki lub organizacje. Staje się to istotne w relacjach z partnerami biznesowymi i klientami.

Psychologowie podkreślają, że przekraczanie granic umożliwia indywidualny rozwój jednostki w organizacjach. Wyniki badań pracy menedżerskiej zrealizowane przez Instytut Gallupa zostały opublikowane w książce pod tytułem „Po pierwsze złam wszelkie zasady” (Buckingham, Coffman, 2004). Autorzy upatrują źródeł sukcesu menedżerów w elastyczności w podchodzeniu do sytuacji i ludzi oraz przekraczaniu i łamaniu utartych zasad, co można utożsamiać z przekraczaniem granic przyjętych w organizacjach.

W ostatnich latach prowadzonych jest wiele badań poświęconych równowadze między życiem zawodowym i prywatnym pracowników (Work-Life Balance). Wielu badaczy wskazuje, że coraz rzadziej można mówić o wyraźnej granicy między tymi dwoma obszarami życia, zwłaszcza wśród pracowników umysłowych (Wróbel, 2014, s. 210). W zamian pojawia się pojęcie nieostrej, zamazanej granicy (Van Dijk, 2010, s. 226). C.E. Nippert-Eng (1996), analizując relacje między życiem zawodowym a prywatnym, wskazuje na cztery rodzaje granic: fizyczne, czasowe, emocjonalne i poznawcze.

Powyższe problemy badawcze nie wyczerpują bogatej literatury $\mathrm{z}$ psychologii organizacji. W bazach $\mathrm{EBSCO}^{2}$ można znaleźć badania dotyczące granic: pomiędzy pracownikami a zewnętrznymi współpracownikami, pomiędzy członkami samoorganizujących się zespołów i grup roboczych w organizacjach opartych na współpracy, pomiędzy interesariuszami a kulturą organizacyjną, pomiędzy satysfakcją z pracy a systemem kontroli, pomiędzy kulturą organizacyjną a potrzebami zawodowymi menedżerów.

\section{Perspektywy wykorzystania kategorii granicy $w$ badaniach organizacji}

D laczego warto $\mathrm{w}$ badaniach organizacji wykorzystywać pojęcie granica? Analiza publikacji wskazuje na bardzo szerokie spektrum możliwych do eksploracji obszarów badawczych. Pojęcie granica jest najczęściej stosowane do:

- opisu tego, co się dzieje na styku organizacja - otoczenie (granice zewnętrzne) - problemy związane np. z zarządzaniem strategicznym, innowacyjnością;

- analizy problemów wewnętrznych organizacji (granice wewnętrzne) - zagadnienia związane np. $\mathrm{z}$ władzą, zachowaniami organizacyjnymi, funkcjonowaniem zespołów.

Na razie niszowym choć szybko zyskującym na znaczeniu obszarem badawczym są granice organizacji sieciowych, granice międzyorganizacyjne (rys. 3).

Granice są wszędzie i zawsze będą. Kluczowe staje się, czy hamują, czy też umożliwiają płynne funkcjonowanie organizacji oraz zapewniają wsparcie do tego, żeby była taka, jaka ma być. Tak jak zmiana granic państwowych prowadzi do transformacji świata, tak zmiana granic organizacyjnych prowadzi do transformacji organizacji. Granice zarówno te wewnętrzne, jak i zewnętrzne postrzegane są przez pracowników w określony sposób, a to wpływa na ich zachowania. Co więcej, na granicach dzieją się ciekawe zjawiska, które wpływają na funkcjonowanie organizacji.

W przyszłości można spodziewać się wzrostu znaczenia kategorii granic w badaniach organizacji. Wpływać na to będzie szereg czynników:

- znaczna niestabilność otoczenia i organizacji;

- tymczasowość relacji zewnętrznych i wewnętrznych;

- potrzeba uelastyczniania organizacji;

- zmieniająca się hierarchia wewnątrz organizacji, proces spłaszczania struktur;

- nowe możliwości zapewniane przez technologię informatyczną.

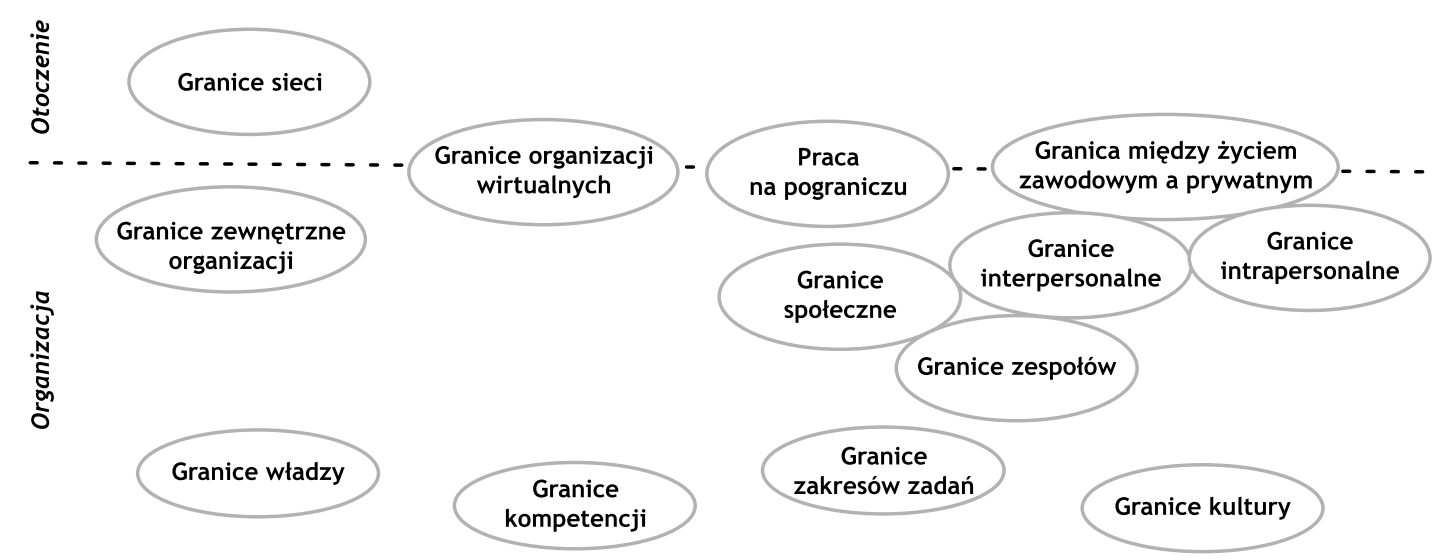

Rys. 3. Przykładowe zastosowania pojęcia granica $w$ badaniach z zakresu zarządzania i psychologii organizacji Źródto: opracowanie wtasne 
Wziąwszy pod uwagę rezultaty przeprowadzonego przeglądu, warto mieć na uwadze, że "granica” jest często traktowana jako wąsko zdefiniowane pojęcie. Tymczasem granicę można traktować także jako teoriotwórczą kategorię. Dotychczas autorzy traktowali $\mathrm{w}$ niniejszym artykule pojęcie i kategorię wymiennie, jednak w tym miejscu warto zwrócić uwagę na pewną subtelną różnicę między tymi słowami. Jako kategoria granica jest dynamiczna, niedookreślona i inaczej niż pojęcie, które jest raczej domknięte i statyczne, pozwala na eksplorowanie takich wymiarów organizacji, które nie cieszą się atencją badaczy. Jednak traktowanie granicy jako kategorii wymaga przyzwolenia na niedookreślenie, raczej na poszerzanie wiedzy o nich niż wąskie definiowanie. $\mathrm{W}$ naukach o zarząadzaniu i jakości występuje tendencja do dookreślania. Zastępuje się pojęcia szerokie, trudne dla operacjonalizacji, terminami bardziej jednoznacznymi zarezerwowanymi dla czegoś konkretnego. Zastosowanie podejścia do granicy jako kategorii pozwoliłoby być może na lepsze zrozumienie współwystępujących i niekiedy opozycyjnych zachowań w organizacjach.

Badając organizacje, zazwyczaj poznajemy ją taką, jaką chce nam - badaczom się ukazać. Przez wyznaczenie hipotez lub pytań badawczych redukujemy nasze postrzeganie. Nie jesteśmy wtedy w stanie dostrzec tego, co jest nieuświadomione, ukryte, wypierane w organizacji, ale jednak istotne dla jej funkcjonowania - sposób postrzegania, myślenia, uprzedzenia, oczekiwania, coś do czego sama organizacja się nie przyznaje. Dopiero przez dopuszczenie wieloznaczności można pozwolić organizacji ukazać jej „cienie”, w których również może tkwić siła. Zadaniem dalszych badań może być poszerzanie naszej wiedzy o organizacjach przez ukazanie tego, co jest po jednej i drugiej stronie "granicy” oraz podjęcie prób wykorzystania tkwiącego tam potencjału. $\mathrm{W}$ ten sposób możliwe jest przekraczanie granic badań, które często hamują rozwój nauki, na co zwraca uwagę wielu badaczy (Wilkin, 2019, s. 57).

\section{Podsumowanie}

$\mathrm{K}$ ategorię granicy można postrzegać w bardzo różnorodny, czasami sprzeczny sposób. Wykorzystanie różnych znaczeń granicy umożliwia przyjęcie nowej perspektywy analizy wielu problemów występujących $\mathrm{w}$ organizacjach oraz $\mathrm{w}$ relacjach organizacja - otoczenie. Dokonany w artykule przegląd zastosowań kategorii granicy ma być $\mathrm{w}$ zamierzeniu autorów przyczynkiem do popularyzacji podejścia opartego na granicach $\mathrm{w}$ badaniach organizacji. Jest to szczególnie cenne $w$ badaniach interdyscyplinarnych, zwłaszcza w paradygmacie interpretatywnym. Granice mogą mieć również zastosowanie jako metafora, która obrazuje zjawiska jednocześnie łączące i dzielące ludzi, zespoły i organizacje, wpisując się w nurt wykorzystania metafor w zarządzaniu.

Ale poza budowaniem lepszej teorii zarządzania warto wskazać na praktyczne implikacje wykorzystania pojęcia granica. Kategoria granic może posłużyć do zadawania kluczowych pytań dotyczących organizacji, a udzielone odpowiedzi mogą wspomóc diagnozę i zainicjować zmiany organizacyjne. Świadome zarządzanie granicami przez menedżerów jest ważne dla sprawnego funkcjonowania organizacji.

\section{dr inż. Dorota Jendza \\ Uniwersytet Gdański \\ Wydział Zarządzania \\ ORCID: 0000-0002-2493-1841 \\ e-mail: dorota.jendza@ug.edu.pl}

\section{dr hab. Piotr Wróbel, prof. uczelni Uniwersytet Gdański \\ Wydział Zarządzania \\ ORCID: 0000-0002-4469-5874 \\ e-mail: piotr.wrobel@ug.edu.pl}

\section{Przypisy}

1) Do terminów powiązanych należą: graniczny, pogranicze, peryferia, ograniczenie, bariera, status-quo, horyzont. W języku angielskim wykorzystywane są takie terminy, jak: boundaries, borders, frontiers, edge, borderland, horizon.

2) Bazy EBSCOhost, PsycARTICLES, PsycINFO (data dostępu: 05.07.2019 r.).

\section{Bibliografia}

[1] Ashkenas R., Ulrich D., Jick T., Kerr S. (1984), The Boundaryless Organization: Breaking the Chains of Organizational Structure, Jossey Bass, San Francisco.

[2] Balmer J.M.T., Wilson A. (1998), Corporate Identity: There is More to It than Meets the Eye, „International Studies of Management and Organization”, Vol. 28, No. 3, pp. 12-31.

[3] Barabasz A. (2008), Osobowość organizacji. Zastosowanie w praktyce zarządzania, Wydawnictwo Akademii Ekonomicznej im. Oskara Langego we Wrocławiu, Wrocław.

[4] Barabasz A. (2014), Granice organizacji w ujęciu psychoanalitycznym, [w:] P. Wachowiak, S. Winch (red.), Granice $w$ zarzadzaniu kapitałem ludzkim, Oficyna Wydawnicza Szkoła Główna Handlowa w Warszawie, Warszawa, s. 61-69.

[5] Barczak B. (2015), Problem poszukiwania granic sieci organizacyjnych, „Przegląd Organizacji”, Nr 5, s. 9-16.

[6] Berg D.N., Smith K.K. (1990), Paradox and Groups, [in:] J. Gillette, M. McCollom (eds.), Groups in Context: A New Perspective on Group Dynamics, Addison-Wesley, Reading, pp. 106-132.

[7] Blicharski M. (2001), Wstęp do inżynierii materiałowej, Wydawnictwa Naukowo-Techniczne, Warszawa.

[8] Buckingham M., Coffman C. (2004), Po pierwsze złam wszelkie zasady, MT Biznes, Warszawa.

[9] Burda M., Wyplosz C. (2009), Macroeconomics: A European Text, Oxford University Press. 
[10] Clark W.C., Tomich T.P., van Noordwijk M., Dickson N.M., Catacutan D., Guston D., McNie E. (2010), Toward a General Theory of Boundary Work: Insights from the CGIAR's Natural Resource Management Programs, RWP10-035, Center for International Development at Harvard University.

[11] Coase R. (1937), The Nature of the Firm, „Economica”, No. 4, pp. 386-405.

[12] Cyfert S. (2012a), Granice organizacji, Wydawnictwo Uniwersytetu Ekonomicznego w Poznaniu, Poznań.

[13] Cyfert S. (2012b), Mechanizmy zarzadzania granicami - propozycja teoretycznego ujęcia i wyniki badań empirycznych, „Współczesne Zarządzanie”, Nr 3, s. 17-24.

[14] Cyfert S., Krzakiewicz K. (2014), Granice w świecie sieciowych $i$ wirtualnych organizacji, [w:] A. Sopińska, S. Gregorczyk (red.), Granice strukturalnej złożoności organizacji, Oficyna Wydawnicza Szkoła Główna Handlowa w Warszawie, Warszawa, s. 47-59.

[15] Czakon W. (2014), Problem granic $w$ badaniach sieci międzyorganizacyjnych, „Studia i Prace Kolegium Zarządzania i Finansów", Nr 135, s. 89-98.

[16] Chitra D., Ganesh M.P. (2017), Team Boundary Activity: A Review and Directions for Future Research, „Team Performance Management", Vol. 23, No. 5/6, pp. 273-292.

[17] De Board R. (1978), The Psychoanalysis of Organizations, Routledge, London.

[18] Dudek Z.W. (2006), Psychologia integralna Junga. Człowiek archetypowy, Eneteia Wydawnictwo Psychologii i Kultury, Warszawa.

[19] Dumez H., Jeunemaitre A. (2010), The Management of Organizational Boundaries: A Case Study, „M@n@gement”, Vol. 13, No. 3, pp. 151-171.

[20] Foucher M. (1991), Fronts et frontieres. Un tour de monde geopilitique, Fayard, Paris.

[21] Hensel P. (2017), Legitymizacja badań organizacji, Wydawnictwo Naukowe PWN, Warszawa.

[22] Hernes T. (2003), Enabling and Constraining Properties of Organizational Boundaries, [in:] N. Paulsen, T. Hernes (eds.), Managing Boundaries in Organizations. Multiple Perspectives, Palgrave Macmillan, pp. 35-54.

[23] Hirschhorn L., Gilmore T. (1992), The New Boundaries of the „Boundaryless” Company, „Harvard Business Review”, No. 5-6, pp. 4-16.

[24] http://dimensions.ai, data dostępu: 08.05.2019 r.

[25] Kislov R. (2018), Selective Permeability of Boundaries in a Boundary Spanning Team, „Academy of Management Proceedings", Vol. 2018, No. 1, https://doi.org/10.1111/ padm.12541.

[26] Kozielecki J. (1987), Koncepcja transgresyjna człowieka, Państwowe Wydawnictwo Naukowe, Warszawa.

[27] Marciszewska A., Jokiel G. (2019), Granice zarzadzania projektami - ujęcie systemowe, „Przegląd Organizacji”, Nr 3, s. 9-14

[28] Mindell A. (1995), Praca nad samym sobą, Nuit Magique, Warszawa.

[29] Nippert-Eng C.E. (1996), Home and work: Negotiating boundaries through everyday life, The University of Chicago Press, Chicago.

[30] Pachura P. (2018), Organizational Boundaries - Contribution to Conceptualization, „Scientific Journal of the Military University of Land Forces", Vol. 50, No. 4(190), pp. 152-161.
[31] Panteli N. (2003), Virtual Interactions: Creating Impressions of Boundaries, [in:] N. Paulsen, T. Hernes (eds.), Managing Boundaries in Organizations. Multiple Perspectives, Palgrave Macmillan, pp. 76-92.

[32] Paulsen N. (2003), „Who Are We Now?”: Group Identity, Boundaries, and the (Re)Organizing Process, [in:] N. Paulsen, T. Hernes (eds.), Managing Boundaries in Organizations. Multiple Perspectives, Palgrave Macmillan, pp. 14-34.

[33] Perechuda K. (2000), Granice przedsiębiorstwa wirtualnego, [w:] J. Lichtarski, H. Jagoda (red.), Nowe kierunki w zarzqdzaniu przedsiębiorstwem - ciagłość i zmiana, Wyd. AE we Wrocławiu, Wrocław, s. 312-317.

[34] Van Dijk J. (2010), Społeczne aspekty nowych mediów, Wydawnictwo Naukowe PWN, Warszawa.

[35] Weick K.E., Roberts K.H. (1993), Collective Mind in Organizations: Heedful Interrelating on Flight Decks, „Administrative Science Quarterly", Vol. 38, No. 3, pp. 357-381.

[36] Wilkin J. (2019), Nauka przekracza wszelkie granice, także w ekonomii, [w:] M. Gorynia (red.), Ewolucja nauk ekonomicznych, Polska Akademia Nauk, Warszawa, s. 57-68.

[37] Wróbel P. (2014), Komunikacja elektroniczna: zagrożenia $i$ ich skutki dla organizacji, Wydawnictwo Uniwersytetu Gdańskiego, Sopot.

\section{Use of Boundary Notion in Organisations - Identification of Research Areas}

\section{Summary}

The aim of the article is to identify the current scale and scope of application of the boundary concept in the organisation's research and determine the possibilities that ensure the use of the boundary category for a better understanding of how organisations work. In the research regarding organisations, the category of the border occurs in different contexts and areas of research. Boundaries in the management literature are treated as external and internal boundaries of the organisation. The research analyses borders of various nature: physical, social and mental ones. The subjects of the interest of researchers are activities undertaken at the border of the organisation and the environment, so-called boundary work. As part of the research of virtual and network organizations, the concept of a boundaryless organisation appears. Organisational psychologists analyse the functioning of intrapersonal, interpersonal and team boundaries. Borders have a dual nature - on the one hand, they provide stability and security, and on the other - cooperation and development. The use of various meanings of the border allows for the adoption of a new perspective to analyse many problems occurring in organisations and in the relations between the organisation and the environment. This is especially valuable in interdisciplinary research, in particular in the interpretive paradigm.

\section{Keywords}

boundaries, frontiers, organisations 